\title{
EFFECT OF SUPPLEMENTATION KAYU MANIS (CINNAMOMUM BURMANNII) EXTRACT IN NEURONAL CELL DEATH PROTECTION IN WISTAR RATS LIR-PSYCHOTIC ON HALOPERIDOL THERAPY
}

\section{RADIYATI UMI PARTAN ${ }^{1}$, RACHMAT HIDAYAT ${ }^{2 *}$, MGS IRSAN SALEH ${ }^{3}$, NITA PARISA $^{3}$, NIA SAVITRI TANZIL ${ }^{3}$}

${ }^{1}$ Department of Internal Medicine, Faculty of Medicine, Sriwijaya University, Palembang, Indonesia. ${ }^{2}$ Biomolecular Laboratory, Faculty of Medicine, Sriwijaya University, Palembang, Indonesia. ${ }^{3}$ Department of Pharmacology, Faculty of Medicine Sriwijaya University, Palembang, Indonesia. Email: dr.rachmat.hidayat@gmail.com

Received: 15 August 2017, Revised and Accepted: 22 November 2017

\section{ABSTRACT}

Objective: The objective of this study was to determine the neuronal cell protective effect from kayu manis extract by inhibition activating active caspase-3 in Wistar rats lir psychotic-like behavior on haloperidol therapy.

Methods: An experimental in vivo study, an 8-week-old male Wistar rats $(\mathrm{n}=30)$ were used. Wistar rats were randomized into six groups. Group A: 5 rats as control without induced psychosis-like behavior and aquadest or drugs. Group B: 5 rats were induced psychosis-like behavior (ketamine $30 \mathrm{mg} / \mathrm{kgBW}$, intraperitoneal for 5 days) and aquadest. Group C: 5 rats were induced psychosis-like behavior and haloperidol $0.5 \mathrm{mg} / \mathrm{kgBW}$, per oral, 28 days. Group D: 5 rats were induced psychosis-like behavior, haloperidol $0.5 \mathrm{mg} / \mathrm{kgBW}$, and kayu manis extract $50 \mathrm{mg} / \mathrm{kgBW}$, per oral, $28 \mathrm{days}$. Group E: 5 rats were induced psychosis-like behavior, haloperidol $0.5 \mathrm{mg} / \mathrm{kgBW}$, and kayu manis extract $100 \mathrm{mg} / \mathrm{kgBW}$, per oral, 28 days. Group F: 5 rats were induced psychosis-like behavior, haloperidol $0.5 \mathrm{mg} / \mathrm{kgBW}$, and kayu manis extract $200 \mathrm{mg} / \mathrm{kgBW}$, per oral, 28 days. Negative symptoms of schizophrenia were assessed by social interactivity test pre and post. Apoptosis of neuronal cells in ventral tegmental area was assessed by immunohistochemistry of active caspase-3. The area stained was calculated as a percentage of total area within a field by program ImageJ.

Results: Active caspase-3 percentage area for group's treatment with only haloperidol was more wide than groups treatment with combination haloperidol and kayu manis extract.

Conclusion: Kayu manis extract can protect neuronal cell death through inhibition activating of active caspase-3 in Wistar rats psychotic-like behavior on haloperidol therapy.

Keywords: Kayu manis (Cinnamomum burmannii), Apoptosis, Psychotic, Rat, Active caspase-3.

(c) 2018 The Authors. Published by Innovare Academic Sciences Pvt Ltd. This is an open access article under the CC BY license (http://creativecommons. org/licenses/by/4. 0/) DOI: http://dx.doi.org/10.22159/ajpcr.2018.v11i2.22024

\section{INTRODUCTION}

Psychotic is an acute symptoms of schizophrenia disorder. Schizophrenia is a psychiatric disorder that occurs in about $1 \%$ of world population. The influence of genetics is believed to play a role in psychiatric disorders, particularly when the disorder has occurred in young adults or teenagers. Clinical symptoms characterized by positive symptoms (delusions, hallucinations, disorganized thinking, speech, and behavior), negative symptoms (loss of motivation, withdrawal from social life and have poor social relationships), and cognitive deficits $[1,2]$.

Haloperidol is one very common antipsychotic used in the treatment of schizophrenia disorder. Haloperidol is a first-generation antipsychotic, which works by blocking the dopamine 2 receptor activity, especially in the area of striatal and mesolimbic area. 2 dopamine receptor activation also activates $\beta$-arrestin- 2 which inhibits the activity of Akt and GSK3protein increase [3]. GSK-3 is a signaling protein that plays a role in neuronal cell survival $[3,4]$. In case of inhibition of dopamine 2 receptor activity by antipsychotics will cause the activation of Akt and decreased activity of GSK-3 that will decrease neuronal cell survival and increase activity of caspase-3.

Cinnamomum burmannii (cassia, Indonesian cassia, cassia field) is one type of cinnamon. This species originated from Indonesia and Southeast Asia. In general, this plant is used as a spice, ornamental plants, as well as forest plants. C. burmannii bark that has an aromatic smell is so used as a spice (cinnamon), perfumes, and drugs. Cinnamon is helpful in treating dyslipidemia, hyperglycemia, and inflammation. Various flavonoids, polyphenols, alkaloids, and tannins found in cinnamon are believed to provide health benefits [5]. Proanthocyanidins a compound which are contained in cinnamon extract, which has antioxidant effects that are strong enough [6]. Proantosianidin role in preventing oxidative stress in experimental animals gastrointestinal mucosa [7]. Proantosianidin compounds from cinnamon extract useful in cell apoptosis inhibit the activity of astrocytes and neuronal cells in ischemic conditions in vitro.

\section{METHODS}

\section{Plant materials}

Kayu manis (C. burmannii) were collected from Gandus Plantation in Gandus District, Palembang, South Sumatera Province, Indonesia, in the month of August-September and were authenticated by the Indonesia Science Institute. The collected plant material was made free from foreign organic matter.

Preparation of aqueous combination extract

The collected kayu manis were washed, rinsed, blotted, sliced, and ground. The extraction process was carried out at $90^{\circ} \mathrm{C}$ for $15 \mathrm{~min}$ in ratio of plant-to-water 1:10. The extract was filtered, concentrated, and evaporated in rotary evaporator.

\section{Animals and treatments}

An 8-week-old male rats (Wistar rat) (weight, 150-200 g) were obtained from Laboratory of Animal Study, Faculty of Medicine Sriwijaya University, Palembang, Indonesia, with approval of the 
Ethics Committee of Bioethics Unit (No. 231/kepkrsmhfkunsri/2017) Faculty of Medicine Sriwijaya University, Palembang, Indonesia. Rats were placed in cages with water and food provided ad libitum and temperature of $24^{\circ} \mathrm{C}-26^{\circ} \mathrm{C}$. They were remained in auditory and olfactory contact with the other rats until use.

The study used 30 animals were randomized into six groups. Group A: 5 rats as control without induced psychosis-like behavior and aquadest or drugs. Group B: 5 rats were induced psychosis-like behavior (ketamine $30 \mathrm{mg} / \mathrm{kgBW}$, intraperitoneal [i. p.] for 5 days) and aquadest. Group C: 5 rats were induced psychosis-like behavior and haloperidol $0.5 \mathrm{mg} /$ $\mathrm{kgBW}$, per oral, 28 days. Group D: 5 rats were induced psychosis-like behavior, haloperidol $0.5 \mathrm{mg} / \mathrm{kgBW}$, and kayu manis extract $50 \mathrm{mg} /$ $\mathrm{kgBW}$, per oral, 28 days. Group E: 5 rats were induced psychosis-like behavior, haloperidol $0.5 \mathrm{mg} / \mathrm{kgBW}$, and kayu manis extract $100 \mathrm{mg} /$ kgBW, per oral, 28 days. Group F: 5 rats were induced psychosis-like behavior, haloperidol $0.5 \mathrm{mg} / \mathrm{kgBW}$, and kayu manis extract $200 \mathrm{mg} /$ $\mathrm{kgBW}$, per oral, 28 days.

\section{Induction of psychosis}

Saline or $30 \mathrm{mg} / \mathrm{kg}$ of ketamine was injected to animals by i. p. for 5 days.

\section{The social interaction test (SIT)}

The test apparatuses consisted of chambers containing pine shavings that were proportionally size for rats, $30 \mathrm{~cm} \times 20 \mathrm{~cm} \times 20 \mathrm{~cm}$. Each test apparatus was divided into two equally sized compartments by a clear partition that contained an aperture, $7 \mathrm{~cm} \times 5 \mathrm{~cm}$, to allow the movement of the animals between compartments. All testing procedures were conducted between 9:00 and 14:00 a.m. The animals were habituated to the test chamber and allowed to freely explore for $15 \mathrm{~min}$. A test animal was placed in one of the two compartments, and the percentage of time the rats spent in the compartment with the test animal was compared to the time spent in the compartment with the empty compartment for 15 min.

\section{Histological procedures}

Detection of active caspase-3 expression was performed with immunohistochemical technique. Animals were anesthetized by injection of ketamine, $60 \mathrm{mg} / \mathrm{kg}$, i. p. and were perfused through the left ventricle. The animals had their chests opened and the perfusion through the left ventricle of the heart, within $<1$ min from chest opening. The perfusion buffer was used for only $2 \mathrm{~min}$ and was then followed by the perfusion fixative. The buffer solution contained $0.1 \%(\mathrm{w} / \mathrm{v})$ Tris, $0.59 \%(\mathrm{w} / \mathrm{v}$ ) calcium chloride, and $0.09 \%(\mathrm{w} / \mathrm{v})$ sodium chloride. Perfusion fixative was contained $2 \%(\mathrm{v} / \mathrm{v})$ paraformaldehyde, $2.5 \%$ $(\mathrm{v} / \mathrm{v})$ glutaraldehyde, $0.1 \%(\mathrm{w} / \mathrm{v})$ Tris, $0.59 \%(\mathrm{w} / \mathrm{v})$ calcium chloride, and $0.36 \%(\mathrm{w} / \mathrm{v})$ sodium chloride, with the final solution $\mathrm{pH}$ adjusted to 7.5. The brains were removed from the skull did not take place at the end of perfusion but only $24 \mathrm{~h}$ later, to avoid dark cell artifacts.

\section{Active caspase- 3 immunohistochemistry}

After $24 \mathrm{~h}$, the brains were removed from the skull. They were fixed in the same solution for $2 \mathrm{~h}$, placed in Tris phosphate-buffered saline (TBS) $\left(\mathrm{pH} 7.4,4^{\circ} \mathrm{C}\right)$ for $24 \mathrm{~h}$, and serially sectioned in $30-\mathrm{mm}$ thick coronal sections on a Cryotome. They were then blocked in TBS containing $3 \%$ normal goat serum (NGS) and $0.3 \%$ Triton X-100 for $1 \mathrm{~h}$, incubated in the rabbit anti-active caspase- 3 serum (Abcam) at a concentration of $1: 1000$ in $3 \%$ NGS and $0.3 \%$ Triton X-100 overnight at room temperature, washed with TBS 3 times for 10 min each time, incubated in biotinylated goat anti-rabbit immunoglobulin G (Sigma) at 1:500 in $1 \%$ NGS and $0.3 \%$ Triton X-100 for $1 \mathrm{~h}$ at room temperature, washed with TBS 3 times for 10 min each time, and then incubated in avidin-biotin-peroxidase complex (Sigma) for $1 \mathrm{~h}$. To identify the immunoreaction product, the horseradish peroxidase was visualized with diaminobenzidine and glucose oxidase, with nickel intensification. Coronal sections approximating $-3.5 \mathrm{~mm}$ to the bregma were used for active caspase- 3 expression in the ventral tegmental area. Both sides of several sections at each level were evaluated to ensure that the regions were truly representative.

\section{Active caspase- 3 percentage area}

Active caspase- 3 percentage area was determined by measuring the area of stained was calculated as a percentage of total area within a field by program ImageJ. In ventral tegmental area, 30 fields were analyzed.

\section{Statistical analysis}

The result is presented as mean \pm standard deviation. Bivariate analysis for SIT and caspase-3 fraction area was analyzed by t-test. Multivariate analysis for SIT and active caspase- 3 fraction area was analyzed by oneway ANOVA, followed post hoc analysis with Bonferroni test. A value of $\mathrm{p}<0.05$ was considered statistically significant.

\section{RESULTS}

\section{SIT}

Negative symptoms of psychosis-like behavior were assessed by SIT. The result was the percentage of time the rats spends in the section with the test animal is compared to the time spent in the section with the empty compartment for $15 \mathrm{~min}$. The result of SIT for groups that induced psychosis-like behavior by ketamine, decreased than the group without induced psychosis-like behavior by ketamine (Table 1).

The result of SIT for groups that treatment with only haloperidol worse than the result of SITs for groups that treatment with haloperidol and kayu manis extract (Table 1). A combination of haloperidol and kayu manis extract was potent to control negative symptoms of psychosis.

\section{Active caspase-3 activity}

Active caspase-3 percentage area for groups treatment with only haloperidol was more wide than groups treatment with combination haloperidol and kayu manis extract (Table 2). Active caspase-3 activity was more active in groups that treatment only haloperidol.

\section{DISCUSSION}

This study demonstrated that haloperidol activates apoptosis neuronal cell through activate of active caspase-3. Haloperidol induces the mitochondrial accumulation of Bcl-XS in PC12 cells and related to the redistribution of cytochrome $\mathrm{c}$ and to hallmarks of apoptotic processes, that is Annexin-V staining as well as the cleavage of caspase- $9[8,9]$ and of PARP [10]. Other study demonstrated increase in proapoptotic Bax induced by haloperidol was linked to p53 transcriptional activity. However, the p53 system could not be related to $b c l-x S$ gene and protein expression or on the resultant loss of cell viability. Interestingly, the haloperidol-induced increase in total cellular Bax did not result in a proportional increase in mitochondrial Bax, thus supporting a negligible role for Bax in our model as well as a possible influence by haloperidol on Bax conformation, oligomerization or cleavage of Bid, an activator of Bax-mediated apoptosis. It is known that Bax can contribute to mechanisms independent of mitochondrial cytochrome c production [11].

Apoptosis will be activated when the internal damage or malfunction occurs and activate signaling cascades that eventually activate caspases, endonucleases, and kill the cell. One of the important functions of apoptosis is the elimination of preneoplastic and neoplastic cells [12]. In most forms of cell suicide, the signaling cascade utilizes reactive oxygen species as essential intermediate messenger molecules [13]. This is the reason that antioxidants are capable of inhibiting apoptosis. Antioxidants such as $\alpha$-tocopherol, which partition into the lipid compartment of cells, or $\mathrm{N}$-acetylcysteine, a free radical scavenger that partitions into the aqueous phase of the cytosol, can delay or inhibit apoptosis [14].

Various extracts of cinnamon, such as ether, aqueous, and methanolic extracts had a potential as antioxidant. A study in vivo showed the bark powder of Cinnamomum verum (10\%) for 90 days produced antioxidant effect as indicated by cardiac and hepatic antioxidant enzymes, lipid conjugate dienes, and glutathione [15]. A study showed cinnamon oil increased the production of superoxide-dismutase [16]. 
Table 1: SIT before and after induction of ketamine

\begin{tabular}{lllll}
\hline No & Group & Before (\%) & $\begin{array}{l}\text { After } \\
\text { induction } \\
\text { ketamine (\%) }\end{array}$ & $\begin{array}{l}\text { After } \\
\text { treatment (\%) }\end{array}$ \\
\hline 1 & $\mathrm{~A}$ & $86.75 \pm 3.24$ & $86.49 \pm 3.11$ & $86.88 \pm 2.98^{\#}$ \\
2 & $\mathrm{~B}$ & $86.67 \pm 3.12$ & $33.45 \pm 3.27$ & $33.51 \pm 2.97^{* \#}$ \\
3 & $\mathrm{C}$ & $86.45 \pm 3.45$ & $33.75 \pm 2.86^{* \#}$ & $30.96 \pm 3.28$ \\
4 & $\mathrm{D}$ & $86.59 \pm 2.34$ & $33.65 \pm 3.32^{* \#}$ & $43.99 \pm 2.87^{* \#}$ \\
5 & $\mathrm{E}$ & $86.72 \pm 2.98$ & $33.48 \pm 3.45^{* \#}$ & $47.96 \pm 3.41^{* \#}$ \\
6 & $\mathrm{~F}$ & $86.89 \pm 3.29$ & $33.78 \pm 2.91^{* \#}$ & $49.68 \pm 2.93^{* \#}$ \\
\hline
\end{tabular}

Group A: 5 rats as control without induced psychosis-like behavior and aquadest or drugs. Group B: 5 rats were induced psychosis-like behavior (ketamine $30 \mathrm{mg} / \mathrm{kgBW}$, i. p. for 5 days) and aquadest. Group C: 5 rats were induced psychosis-like behavior and haloperidol $0.5 \mathrm{mg} / \mathrm{kgBW}$, per oral, 28 days. Group D: 5 rats were induced psychosis-like behavior, haloperidol $0.5 \mathrm{mg} / \mathrm{kgBW}$, and kayu manis extract $50 \mathrm{mg} / \mathrm{kgBW}$, per oral, 28 days. Group E: 5 rats were induced psychosis-like behavior, haloperidol $0.5 \mathrm{mg} / \mathrm{kgBW}$, and kayu manis extract $100 \mathrm{mg} / \mathrm{kgBW}$, per oral, 28 days. Group F: 5 rats were induced psychosis-like behavior, haloperidol $0.5 \mathrm{mg} / \mathrm{kgBW}$, and kayu manis extract $200 \mathrm{mg} / \mathrm{kgBW}$, per oral, 28 days. ${ }^{*} \mathrm{p}<0.05$ after induction ketamine versus after treatment. \#p< 0.05 group A, B, D, E, F after treatment versus Group $\mathrm{C}$ after treatment. SIT: Social interaction test

Table 2: Percentage area of active caspase-3

\begin{tabular}{lll}
\hline No & Group & Percentage area $(\%) \pm$ SD \\
\hline 1 & A & $1.23 \pm 0.12$ \\
2 & B & $21.34 \pm 2.21$ \\
3 & C & $29.87 \pm 2.56$ \\
4 & D & $17.69 \pm 1.86^{*}$ \\
5 & E & $15.57 \pm 1.34^{*}$ \\
6 & F & $13.07 \pm 1.12^{*}$ \\
\hline
\end{tabular}

Group A: 5 rats as control without induced psychosis-like behavior and aquadest or drugs. Group B: 5 rats were induced psychosis-like behavior (ketamine $30 \mathrm{mg} / \mathrm{kgBW}$, i. p. for 5 days) and aquadest. Group C: 5 rats were induced psychosis-like behavior and haloperidol $0.5 \mathrm{mg} / \mathrm{kgBW}$, per oral, 28 days. Group D: 5 rats were induced psychosis-like behavior, haloperidol $0.5 \mathrm{mg} / \mathrm{kgBW}$, and kayu manis extract $50 \mathrm{mg} / \mathrm{kgBW}$, per oral, 28 days. Group E: 5 rats were induced psychosis-like behavior, haloperidol $0.5 \mathrm{mg} / \mathrm{kgBW}$, and kayu manis extract $100 \mathrm{mg} / \mathrm{kgBW}$, per oral, 28 days. Group F: 5 rats were induced psychosis-like behavior, haloperidol $0.5 \mathrm{mg} / \mathrm{kgBW}$, and kayu manis extract $200 \mathrm{mg} / \mathrm{kgBW}$, per oral, 28 days. ${ }^{*} \mathrm{p}<0.05$ versus group C. SD: Standard deviation

The aqueous and alcoholic extract (1:1) of cinnamon potentially significantly inhibits fatty acid oxidation and lipid peroxidation in vitro [14]. Different flavonoids isolated from cinnamon have free radical scavenging activities and antioxidant properties $[17,18]$. Cinnamaldehyde and other compounds of cinnamon had a potential effect to decrease the production of nitric oxide. The highest inhibitory activities were reported as $81.5 \%, 71.7 \%$, and $41.2 \%$ at $1.0,0.5$, and $0.1 \mu \mathrm{g} / \mu \mathrm{L}$, respectively [18]. The antioxidant activity of two different extracts in vivo, the ethanolic and hot water extracts of the dry bark of $C$. cassia. The significant inhibition was exhibited $(96.3 \%)$ by ethanolic extract of $C$. cassia compared to $\alpha$-tocopherol (natural antioxidant) (93.74\%) [19].

\section{CONCLUSION}

Kayu manis extract can protect neuronal cell death through inhibition activating of active caspase-3 in Wistar rats psychotic-like behavior on haloperidol therapy.

\section{ACKNOWLEDGMENTS}

This study was supported by research foundation from faculty of medicine Sriwijaya University, Palembang, Indonesia. We thank to Yeni Agustin, S. Si, M. Kes and Maisha Pusrita, ST, for her assistance with immunohistochemistry active caspase-3 assay.

\section{REFERENCES}

1. Lewis DA, Lieberman JA. Catching up on schizophrenia: Natural history and neurobiology. Neuron 2000;28:325-34.

2. Sathiya S, Babu CS. Telmisartan alleviates nitrosative stress in turn dopaminergic degeneration in mice mptp model of parkinsonismbiochemical and histopathological evidences. Int J Pharm Pharm Sci 2013;7:97-101.

3. Javitt DC. Glycine transport inhibitors and the treatment of schizophrenia. Biol Psychiatr 2008;63:6-8.

4. Frankle TF. PI3K/Akt: Getting it right matters. Oncogene 2008;27:6473-88.

5. Niizuma K, Endo H, Chan PH. Oxidative stress and mitochondrial dysfunction as determinants of ischemic neuronal death and survival. J Neurochem 2009;109 Suppl 1:133-8

6. Ranasinghe P. Effects of Cinnamomum zeylanicum (Ceylon cinnamon) on blood glucose and lipids in a diabetic and healthy rat model. Pharmacogn Res 2012;4:73-9.

7. Fine AM. Oligomeric proanthocyanidin complexes: History, structure, and phytopharmaceuticalapplications. Altern Med Rev 2000;5:144-51.

8. Zayachkivska OS, Gzhegotsky MR, Terletska OI, Lutsyk DA, Yaschenko AM, Dzhura OR. Influence of Viburnum opulus proanthocyanidins on stress-induced gastrointestinalmucosal damage. J Physiol Pharmacol 2006;57:155-67.

9. Lindenboim L, Yuan J, Stein R. Bcl-xS and bax induce different apoptotic pathways in PC12 cells. Oncogene 2000;19:1783-93.

10. Braun T, Dar S, Vorobiov D, Lindenboim L, Dascal N, Stein R. Expression of Bcl-x(S) in Xenopus oocytes induces BH3-dependent and caspase-dependent cytochrome c release and apoptosis. Mol Cancer Res 2003;1:186-94.

11. Yu SW, Wang H, Poitras MF, Coombs C, Bowers WJ, Federoff HJ, et al. Mediation of poly (ADP-ribose) polymerase-1-dependent cell death by apoptosis-inducing factor. Science 2002;297:259-63.

12. Martinou JC, Desagher S, Antonsson B. Cytochrome c release from mitochondria: All or nothing. Nat Cell Biol 2000;2:E41-3.

13. Vrablic AS, Albright CD, Craciunescu CN, Salganik RI, Zeisel SH. Altered mitochondrial function and overgeneration of reactive oxygen species precede the induction of apoptosis by 1-O-octadecyl-2-methylrac-glycero-3-phosphocholine in p53-defective hepatocytes. FASEB J 2001;15:1739-44.

14. Salganik RI, Albright CD, Rodgers J, Kim J, Zeisel SH, Sivashinskiy MS, et al. Dietary antioxidant depletion: Enhancement of tumor apoptosis and inhibition of brain tumor growth in transgenic mice. Carcinogenesis 2000;21:909-14.

15. Shobana S, Naidu KA. Antioxidant activity of selected Indian spices. Prostaglandins Leukot Essent Fatty Acids 2000;62:107-10.

16. Dhuley JN. Anti-oxidant effects of cinnamon (Cinnamomum verum) bark and greater cardamon (Amomum subulatum) seeds in rats fed high fat diet. Indian J Exp Biol 1999;37:238-42.

17. Kim SJ, Han D, Moon KD, Rhee JS. Measurement of superoxide dismutase-like activity of natural antioxidants. Biosci Biotechnol Biochem 1995;59:822-6.

18. Phukan P, Bawari M, Sengupta M. Promising neuroprotective plants from north-east India. Int J Pharm Pharm Sci 2015;7:28-39.

19. Okawa M, Kinjo J, Nohara T, Ono M. DPPH (1,1-diphenyl-2Picrylhydrazyl) radical scavenging activity of flavonoids obtained from some medicinal plants. Biol Pharm Bull 2001;24:1202-5.

20. Lee HS, Kim BS, Kim MK. Suppression effect of Cinnamomum cassia bark-derived component on nitric oxide synthase. J Agric Food Chem 2002;50:7700-3.

21. Lin CC, Wu SJ, Chang CH, Ng LT. Antioxidant activity of Cinnamomum cassia. Phytother Res 2003;17:726-30. 